\title{
Differential inclusion through education: Reforms and spatial justice in Finnish education policy
}

\author{
Kettunen, M. \& E.-K. Prokkola
}

The paper studies the changing spatial rationalizations of Finnish education policy with a particular focus on upper secondary education, which has gone through significant reforms in recent decades. The fostering of social and spatial equality has long represented the cornerstone of Finland's Nordic welfare state education system. The establishment of a widespread network of educational institutions also formed an important means of building social and territorial cohesion in the country. Since the late 1980s, Finnish education policies have turned towards neoliberal ideals, underlining economic rationalizations, individualization and flexibility. Also, education policy has come to play an increasingly important role in the constitution of the knowledge-based economy and embedded spatial restructuring. The paper scrutinizes recent state upper secondary education reforms from the perspective of spatial justice and its scalar dimensions, underlining the consequential juncture of choosing between upper secondary education paths. It is shown how the rationalization of Finnish education policy differentiates places, favouring urban over rural, and produces particular citizen-subjects: while general upper secondary education forms a site for producing skilled and globally minded citizens, vocational education prioritizes the availability of regional workforce and the prevention of youth marginalization. Rather than providing equal opportunities, it is argued that the dual-path Finnish education policy reinforces spatial differentiation and the differential inclusion of citizen-subjects in the knowledge-based economy.

Key words: spatial justice, citizen-subject, educational reform, upper secondary education, Finland

Corresponding author: Marika Kettunen, University of Oulu, P.O. Box 3000, Oulu FI90014, Finland. Email: marika.kettunen@oulu.fi 


\section{Introduction}

Justice and equality have traditionally been central tenets of the education policies in Finland and other Nordic countries (Dovemark et al., 2018; Järvinen and Vanttaja, 2001). Education, professional skills and life-long learning have become even more important constituents in modern, technology-driven societies. To respond to the perceived needs of the state and the knowledge-based economy, governments in Finland and in the other Nordic countries have continuously introduced new educational reforms, which have been shown to accommodate neoliberal ideals of accountability, evaluation, choice, competition and individualization, and promote the construction of particular kind of subjectivities (Johannesson et al., 2002; Mayo, 2015). These new modes of neoliberal governance as well as the transition towards a global knowledgebased economy challenge the notions of social and spatial equality which the Finnish educational system has been praised for (Beach, 2017; Tervasmäki et al., 2018).

The educational reforms and changing educational discourses in the Nordic countries have garnered a great deal of interdisciplinary interest, particularly with respect to topics such as inequality (e.g. Beach, 2017) and educational governance (e.g. Dovemark et al., 2018; Johannesson et al., 2002). Political geographies of education have focused on researching the production of political subjects and resistance in schools (Mitchell, 2018; Thiem, 2009) as well as on investigating higher education, its spatial implications and regional engagements (Moisio and Kangas, 2016; Paasi, 2005; Peer and Penker, 2016). In most studies, the focus has been on the governance and spatial rationalization of education from the perspective of the state or comparison between states. Less attention has been given to spatially and regionally differentiated inclusions and exclusions and related implications for subject formation within state education systems (see, however, Mitchell, 2018). Higher education plays a crucial role 
in the production of the human capital that a knowledge-based society inevitably presumes; however, from the perspective of spatial justice and citizen-subject formation, it is good to note that a consequential juncture confronts students earlier in the education path as well.

This paper takes up the issue of spatial justice in education reforms and pays attention to the ways in which the rationalization of educational needs is constructed within and through different spatial and scalar dimensions, and how this rationalization is entangled with educational subject formation. Particular focus will be on upper secondary education in Finland, which we argue represents a spatially consequential juncture in the educational path of an individual. In the Finnish education system, 9thyear students must choose between two possible upper secondary education paths - the vocational path and the academic path - which is often the first major differentiating event after their comprehensive education. Thus, the choices made by 15-16-year-old youths regarding upper secondary education have far-reaching individual and societal consequences and implications for citizen-subject formation (cf. Warrington, 2008).

The paper brings together literature from educational governance, state spatial restructuring, and spatial justice. It contributes to political geographies of education by developing further the spatial justice perspective and by examining upper secondary education reforms in Finland. By spatial justice we specifically address distributive and recognitive dimensions (Fraser, 1997), taking into account both structurally and culturally embedded injustices. Studying the rationalization of education policies and educational reforms from the perspective of space and spatial justice, within and through different scalar dimensions, discloses prevailing societal values and sheds light on often unnoticed spatial injustices in educational trajectories. 
The spatial equality of education, and thus opportunities and future prospects, is a highly topical question globally as well as in Europe, which has witnessed a territorially founded wave of populism, "the revenge of the places that don't matter" (Rodríguez-Pose, 2018). The fostering of educational opportunities is thus a way of implying that certain places, people, and their futures matter. A spatial perspective on Finnish upper secondary education is particularly fruitful because, despite the official aim towards social and spatial justice, spatial differences in educational attainment levels are remarkable between and within urban and rural areas, and family background remains a strong predictor of future educational attainment (Saari et al., 2016). Politicians and researchers alike have voiced increasing worries over the state of social and spatial equity in the Finnish education system, which is seen to have resulted in greater social, spatial, and economic polarization (e.g. Tervasmäki et al., 2018). The concern has been taken up by the current Finnish Government in the form of The Right to Learn development programmes (2020-2022) which aim to secure quality and equality in early childhood and comprehensive education. Such initiatives, however, do not recognize the spatial differentiation of educational opportunities and paths.

The paper is structured so that it first discusses the concept of educational and spatial justice and then introduces the Finnish educational system and the history of the country's educational reforms. The research material, consisting of policy documents and educational plans, are analysed and interpreted diachronically and with a focus on the spatial rationalization as well as the political context of the educational reforms. Finally, the paper discusses the problematics of subject formation in Finnish upper secondary education, the changes introduced by the reforms and how subject formation and spatial justice are interlinked. 


\section{Spatializing justice in educational contexts}

In the context of educational research, scholars from various fields have traditionally concentrated on issues of social justice, paying attention to topics such as gender (e.g. Dillabough, 2016), ethnicity (e.g. Holmberg et al., 2018), and socio-economic circumstances (e.g. Francis et. al., 2017). Moreover, there is a growing interest in issues of spatial disparities both in urban (e.g. Bernelius and Vaattovaara, 2016; Thiem, 2009) and rural contexts (Armila et al., 2018; Farrugia, 2016). However, less scholarly attention has been directed to investigating spatial justice within the political context and the state-wide educational trajectories of upper secondary education. The concept of spatial justice provides a fruitful analytical lens for studying state educational reforms, allowing insights into the ways in which reforms are rationalized in policymaking and into what kinds of citizen-subjects are constructed through upper secondary education. We acknowledge that the citizen-subjects constructed in policy discourses do not necessarily manifest as such in educational practices or young citizens' educational subjectivities. As political geographers have pointed out, formal education forms only one, albeit significant, site for citizen-subject formation, which is affected by the wider socio-political framework, institutional structures and practices, and the citizen-subjects themselves (e.g. Kallio and Mitchell, 2016; Mitchell, 2018; Staeheli, 2011). With a focus on educational policy and its transformation, the quality and location of formal educational institutions becomes a key question of spatial justice.

Furthermore, over the last few decades, researchers have voiced increasing concerns over spatial inequalities and the problematic of spatial justice, especially with regards to the shifting political atmosphere and neoliberal reforms (Harvey, 2005; Jones et al., 2019). A geographical focus on justice in education broadens the understanding of injustices that are inherently social and spatial by looking at "the ways in which 
various forms of injustice are manifest in the very process of spatialization” (Dikeç, 2001: 1785; see Soja, 2010). Despite that justice and a just society are shared objectives for many, the conceptions of what constitutes just, fair or equal and the means to reach it vary significantly (Power, 2012; Smith, 2012). MacIntyre (1988) claims that there are differing and incompatible rationalizations behind different conceptualizations of justice, and thus examining the rationalizations of education in relation to space can provide insights about spatial justice in educational contexts. This paper emphasizes an integrative approach on spatial justice, which highlights weaving together theorizations of social justice and space (Dikeç, 2001; Soja, 2010) and bringing together both the distributive and recognitive paradigms within justice theorizations (Fraser, 1997; Gewirtz, 1998; Young, 1990).

In so-called territorial approaches, spatial justice is often coupled with the distributive paradigm and used with reference to justice in terms of fair distribution of benefits and resources (e.g. Rawls, 1971; Smith, 2012). However, what constitutes fair distribution is contextual and dependent on prevailing rationalizations and prevailing societal values. Equality of opportunity has been regarded as one of the main characteristics of the Finnish education system, and it aligns with libertarian notions of justice that emphasize treatment according to merit and prioritize individual liberty and freedom of choice (Smith, 2012: 7-12). The distributive dimension of spatial justice therefore addresses the socioeconomic injustices and material aspects that produce inequality. Processes like centralization of service structures and educational institutions can be seen as uneven development that results in inequalities in rural and peripheral areas (e.g. Armila et al., 2018). In order to provide citizens with equal opportunities and to alleviate socio-economic injustices caused by unfair distribution, redistribution of benefits and resources to alleviate socio-economic injustices is required (Fraser, 1997). 
Critical theorists, however, argue for conceptualizing justice beyond the distributive paradigm. Young (1990) argues that the distributive approach is incapable of addressing the complexities of injustice and that focusing merely on distribution ignores the institutional and structural context of the nature and suitability of educational resources (see Gewirtz, 1998). Similarly, in her theorization of social injustices, Fraser (1997) calls for differentiating distributive approaches and socioeconomic injustices from recognitive approaches and cultural injustices. In Fraserian (Fraser, 1997) terms, such recognitive spatial justice in educational contexts would also take into account cultural and symbolic injustices; it should pay attention to what kind of education is regarded as important, what kind of citizen-subjects are valued, and should consider the struggle towards recognition, as well as valuing difference and diversity.

As Fraser (1997: 11) points out, dismantling spatial injustices requires consideration of both redistribution and recognition. Indeed, in real life the two dimensions of justice are mutually intertwined and may in some cases be contradictory or work at cross purposes (Fraser, 1997; Gewirtz, 2006) - a process of redistribution necessitates identifying those in need of resourcing, and this may in turn lead to marginalization or exclusion (see Fraser, 1997). However, approaching spatial justice as an integrative concept and utilizing the distinction of distributive and recognitive approaches (Fraser, 1997: 13) helps to illuminate the complex nature of justice and its spatial dimensions (Waitoller and Annamma, 2017). In this paper, spatial justice is employed as an analytical lens for studying state educational reforms, taking into account the distinction of cultural politics of recognition and social and regional politics of redistribution (Fraser, 1997) in educational reforms. 
Guided by MacIntyre's (1988) idea that differing rationalizations account for differing conceptualizations of justice, the analysis commences with tracing spatial rationalizations and then proceeds to investigating the implications for spatial justice and citizen-subjects that these rationalization discourses construct. Geographical scales (region, state, transnational, global) and the urban-rural categorization are utilized as an analytical framework for investigating the spatial dimensions of rationalization regarding educational strategies and reforms. Socially constructed scales, scalar hierarchies, and categorizations are understood as discursive devices entangled with normative assumptions about what constitutes just, proper, and legitimate (see Delaney and Leitner, 1997), and therefore provide a relevant framework for investigating spatial justice and citizen-subject formation.

\section{Upper secondary education reforms and spatial restructuring in Finland}

Modernizing the entire education system and establishing universal education, as a facet of universal social policies, were important constituents of the emerging welfare state in post-war Finland (Hiilamo, 2014: 303; Järvinen and Vanttaja, 2001). The historical development of the Finnish education system is rooted in redistributive Keynesianism and a regionally balanced school network contributed to the social and territorial cohesion of the country (Laukia, 2013: 273-274). Establishing an extensive and geographically comprehensive education network was a result of regional and educational politics from the 1960s onwards, when education and especially vocational education began to be considered as a regional development and policy issue.

The development towards a coherent upper secondary education system was initiated in the 1970s and 1980s as the Finnish comprehensive school system was established and the former two-tier system was abolished (Lampinen, 1998; Laukia, 2013). With an emphasis on the equal distribution of educational institutions and 
opportunities, the aim of the reform was to establish social justice and reduce ruralurban differences in educational attainment by providing all citizens with equal educational opportunities irrespective of socio-economic background or place of residence (Government proposal, 44/1967). Comprehensive school reforms in the 1970s and 1980s spurred the development of the upper secondary education structure, which developed as a dual structure, consisting of separate vocational and academic paths.

In present-day Finland, equal access to education is a guiding principle (MEC, 2019) and all schools are state funded and predominantly public. One-year, pre-primary education followed by a nine-year comprehensive education is compulsory; this is followed by a three-year upper secondary education that consists of vocational education and training (VET) or general upper secondary education (GUS). ${ }^{1}$ For the time being, it is possible for young citizens to not enter either of the upper secondary paths, which is regarded as an indicator of youth marginalization. However, to tackle youth marginalization and raise the employment rate, the Finnish Government reported its intention to raise the school-leaving age from 16 to 18 from 2021 onwards (Government Programme, 2019). Marginalization is bound up with the changing requirements of the labour market, that is, the transformation towards a knowledgebased economy has increased the significance of upper secondary education, as formal education is expected to provide students with needed qualifications (see Butler and Hamnett, 2007).

Simultaneously, the distribution of educational opportunities has weakened along with the centralization of educational institutions. Whereas the number of institutions providing VET or GUS rose until the 1980s, it started to diminish at the end of the 1980s along with diminishing youth cohorts and shifts in political reasoning. The late 1980s and early 1990s in Finland were marked by increasingly market-oriented and 
neoliberalist policies, and these ideological, political, and societal changes have led to a distinctive shift and re-evaluation of Finnish educational policies (Järvinen and Vanttaja, 2001; Varjo and Kauko, 2008) and consequent spatial and organizational restructuring of the institutions of upper secondary education. Many educational institutions have merged together or have closed down altogether. Between 2005 and 2019, the number of institutions providing GUS had decreased by 19\% and VET by 54\% (Statistics Finland). This has resulted in educational vacuums in rural and sparsely habited areas (cf. Armila et al., 2018), signalling a decreased interest to invest in these places and their future prospects.

Despite that upper secondary education is often referred to as one coherent educational structure, the reality is that the two paths are treated and valued differently. VET has traditionally been regarded as a practice-oriented path. In rural areas, VET was considered an important resource that contributed to the transformation towards a postagricultural society and enabled diversification of rural livelihoods by providing skilled workforce. Providing education in rural areas was hoped to decelerate rural outmigration and alleviate perceived social problems in growing cities (Kivinen et al., 1989; Laukia, 2013: 231-236). In contrast, GUS has developed as an academically oriented path that provides broad education and knowledge and leads to higher education. It has traditionally been connected to success in previous studies and regarded as an extension of the comprehensive education and its contents.

Although GUS and VET are considered equal in that both provide eligibility for higher education, only a small share of students with a vocational background continue their studies in higher education. Higher education comprises of universities and universities of applied sciences (UAS), the latter of which were established in the mid1990s to provide vocationally oriented higher education and to alleviate the pressure of 
new graduates from GUS who applied to universities and to reduce the amount of people acquiring several degrees in the upper secondary level. However, the vast majority of those who apply and are accepted to study in university have followed the GUS path. By this means, the choice made regarding upper secondary education has consequences for future educational attainment and citizen-subject formation (Figure 1).

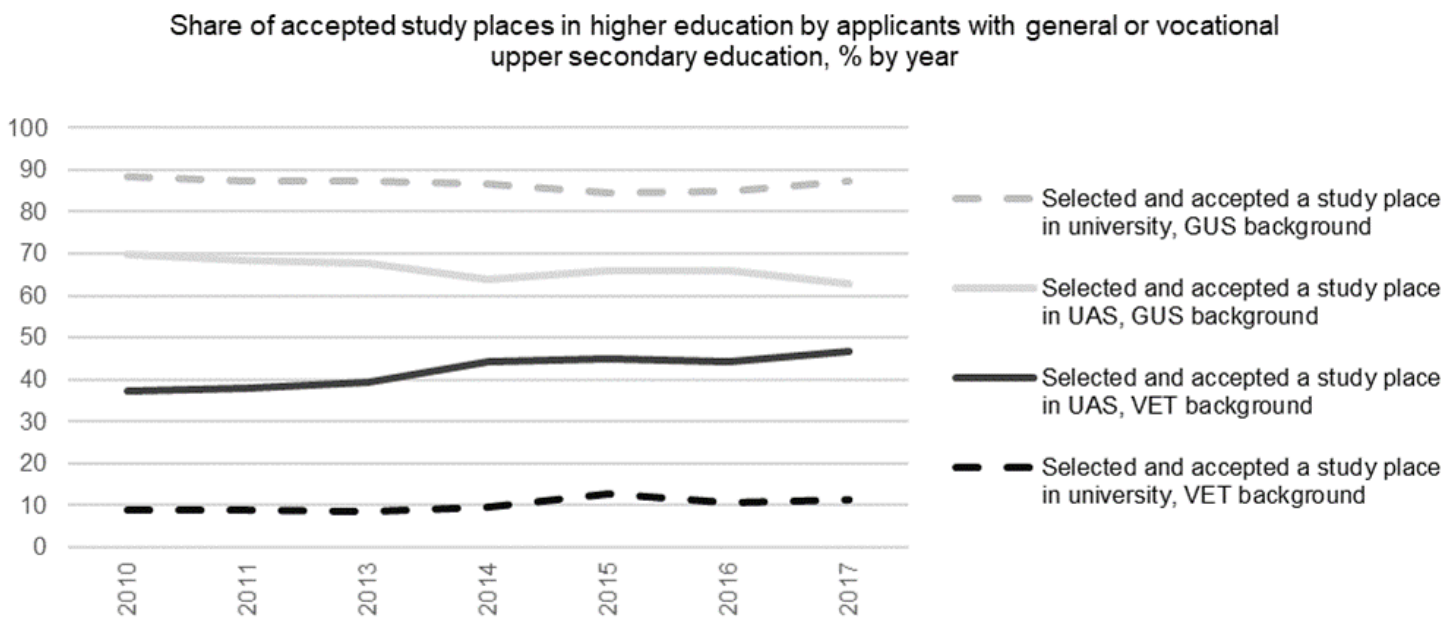

Figure 1. In the year 2017 of the students who applied and accepted a study place in university, $86 \%$ had completed GUS and $10 \%$ had vocational qualifications (Source: Statistics Finland).

\section{Material and methods}

To investigate the spatial rationalization of upper secondary education and its historical development in Finland in relation to spatial justice, we collected and analysed national parliamentary documents related to educational reforms. The methodological approach is guided by critical discourse analysis (Fairclough, 2010), which emphasizes the interrelations between discourses of rationalization and material development as well as the context in which the texts were generated (see Taylor, 2004). The research material covers a thirty-year period from 1987 to 2019 and focuses in particular on changes in Finnish educational governance through upper secondary education reforms (Table 1). 
The main governmental policy documents steering national educational policies in Finland are government programmes and their respective development plans for education and research. These altogether nine government programmes (1987-2015) and corresponding seven development plans regarding education (1987-2012) constitute the core research materials that were used to analyse national educational policies. Political documents are regarded as reflecting the elected government's visions and desired goals, and therefore as technologies of governance used to realize the desired objectives and citizen-subjects (Miller and Rose, 2008). To address the diversity in the establishment of political decision-making and rationalizations and the continuous struggle taking place in such processes (e.g. Ball, 1997), additional material such as policy reports, statistics, government proposals and opposition interpellations (Finnish Parliament, n.d.) are included.

Table 1. Analysed documents grouped by government terms.

\begin{tabular}{|c|c|c|c|}
\hline $\begin{array}{l}\text { Government term by } \\
\text { Prime Minister }\end{array}$ & $\begin{array}{l}\text { Government } \\
\text { programme }\end{array}$ & $\begin{array}{c}\text { Development } \\
\text { plan }\end{array}$ & Additional material \\
\hline Holkeri 1987-1991 (National Coalition Party) & $\mathrm{x}$ & $\bar{x}$ & \\
\hline Aho 1991-1995 (Centre Party) & $x$ & $\mathrm{x}$ & $\begin{array}{l}\text { Government proposal 319/1994 } \\
\text { Decree 256/1995 }\end{array}$ \\
\hline Lipponen 1995-1999 (Social Democrat) & $\mathrm{x}$ & $\mathrm{x}$ & Government proposal 62/1996 \\
\hline Lipponen II 1999-2003 (Social Democrat) & $x$ & $\mathrm{x}$ & $\begin{array}{l}\text { Government proposal } 86 / 1997 \\
\text { Government proposal } 213 / 1998 \\
\text { Decree } 630 / 1998 \\
\text { Decree } 629 / 1998\end{array}$ \\
\hline Vanhanen 2003-2007 * (Centre Party) & $\mathrm{x}$ & $\mathrm{x}$ & $\begin{array}{l}\text { Interpellation } 1084 / 2005 \\
\text { Act } 601 / 2005\end{array}$ \\
\hline Vanhanen II 2007-2010 (Centre Party) & $x$ & $x$ & \\
\hline Katainen 2011-2014 (National Coalition Party) & $x$ & $x$ & \\
\hline Stubb 2014-2015 ** (National Coalition Party) & $\mathrm{x}$ & & Government proposal 12/2014 \\
\hline $\begin{array}{l}\text { Sipilä 2015-2019 (Centre Party) } \\
\text { * Continuation of Jäätteenmäki's government } \\
\text { ** Continuation of Katainen's government }\end{array}$ & $x$ & & $\begin{array}{l}\text { Government proposal 39/2017 } \\
\text { Government proposal } 41 / 2018 \\
\text { Government proposal } 235 / 2018 \\
\text { Interpellations } 4 / 2017 \& 1 / 2018\end{array}$ \\
\hline
\end{tabular}

In the analysis, a spatial justice framework guided by justice theorizations is utilized to address spatial justice, which in the Finnish educational and Nordic educational model context are traditionally expressed as concerns about equality and equal opportunities (see Beach, 2017). Using this spatial justice framework allows the researcher to grasp the multidimensional nature of the education and justice issues beyond the explicitly 
stated Finnish equality discourse and to study the embedded citizen-subject formation and spatial differentiations in educational policies. When reading the governmental documents and educational development plans, particular attention was given to the sections that addressed spatial dimensions and scalar constructions in educational policies and reforms, and especially to the rationalizations of upper secondary education and articulations of educational subjectivities. Since rationalizations of justice are historically situated (MacIntyre, 1988: 390), the analysis is supplemented with a historical periodization contextualizing the educational changes and reforms within the wider socio-political changes of the research period (cf. Taylor, 2004), depicting how the spatial and scalar articulations have changed over time.

The chosen timeframe, starting from 1987 when the first development plan for education and research was created, could be described as an era of shifting political and societal atmosphere in the welfare state and its educational policies (see Ahonen, 2001). The early 1990s represents the beginning of a period marked by global economic recession, shifting political power relations and emerging globalization and neoliberal policies, all of which have affected Finnish educational policies (Dovemark et al., 2018; Simola et al., 2002). Against this backdrop, in the next sections we will examine, first, the articulations and production of spatial rationalization in the Finnish upper secondary education reforms between 1987 and 2019, and second, the production of educational subjectivities. In addition, the implications of educational reforms will be discussed from the perspective of scalar dimensions of spatial justice. 


\section{Periodization and educational reforms in Finland 1987-2019}

\section{Neoliberalizing Finnish education: Recession and shifting political atmosphere}

1987-1994

The late 1980s was marked by economic and geopolitical changes that affected the Finnish education system: the opening of the Iron Curtain, the collapse of the Soviet Union and the opening of the state economy to global markets (e.g. Simola et al., 2002). Although the narrative of state neoliberalization can be traced to the liberalization of financial markets initiated in the mid-1970s, in Finland the deep period of recession at the beginning of the 1990s represents the crucial turning point in state policy (Patomäki, 2007) and the educational system.

Already before the economic downturn, the Finnish government (Government programme, 1987) had initiated what was termed a controlled structural change, which was argued to be needed to stabilize the transforming economy by steering the focus towards technology in order to raise the country's competitiveness in foreign markets (Alestalo, 1993). The government programme (1987) stated that the focus of regional development would be on education and new technology: "The government promotes the implementation of new technology in every part of the country. The focus of regional policies and support is to be shifted towards education, skills, and knowhow" (Government programme, 1987: 6). These initiatives towards regional and educational restructuring were disrupted by challenges posed by the economic recession and increased unemployment rates, as Finland had the second highest unemployment rate in Europe (Järvinen and Vanttaja, 2001). There was a pressing need for cutbacks in the welfare state; budget cuts were introduced, and the reshaping of the school network began in earnest. 
In the 1990's reform, GUS was developed largely as a part of comprehensive education, but VET, considered scattered and incoherent, was seen to face urgent restructuring needs. The government introduced a rationalization plan (Government programme 1991) to increase the efficiency of the educational system. In line with the doctrine of New Public Management - which seeks to enhance the efficiency of the public sector, preferring the outsourcing of public services and the building of businesslike markets within public organizations (see Patomäki, 2007) - the number of educational institutions was reduced as state institutions were merged, privatized, or delegated to the municipalities. In 1994-1995 alone, 96 vocational institutions were to be merged into 42 and 13 were to be closed down altogether (Development plan, 1991), fostering the centralization of educational institutions. The objective was also to make the system more consistent by restructuring vocational upper secondary qualifications into broader basic degrees. Reflecting the prevailing individualizing ethos in educational politics, during the 1990s many GUS institutions started providing education with a special emphasis.

In the Government programme (1991), the discourses of controlled structural change shifted towards emphasizing national survival and the need to raise the effectiveness of the education system on all levels, thus linking education, employment, and arguments of state survival. Education and educated citizens were presented as key to solving the economic crisis and helping the country get back on the economic growth track.

Finland as an emerging knowledge-based economy in the European union 19952002

Finland joined the European Union in 1995 and closer European cooperation paved the 
way for internationalizing the national education system and harmonizing educational structures within the EU. International rankings and new instruments to measure the development and quality of education were introduced; Finnish pupils' skills in mathematics and natural sciences were compared with other OECD countries to rationalize development measures (Development plan, 1996: 7). Educational policies adopted the EU-level concept of lifelong learning as a means to cope with the changing world and technological developments, reshaping the ideal citizen-subject and their skills.

In the Lisbon Treaty of 2000, Finland along with the other EU member states agreed on "a new strategic goal for the Union in order to strengthen employment, economic reform and social cohesion as part of a knowledge-based economy" (European Parliament, 2000). The objectives of the knowledge-based economy had already been adopted in Finland and the government programme of the 1999 explicitly highlights the transformation towards a knowledge-based economy: "Finland will be established as a knowledge society in which knowledge and skills are part of education ${ }^{2}$ and the most important mode of production. Finland must become a pioneer nation in prioritizing technology" (Government programme, 1999: 13). Alongside humanist ideals of education, "knowledge" and "skills" came to be understood as a mode of production, and came to be linked to technological development and innovations, which are seen as fostering national economic competitiveness. From the perspective of the state, institutionalized forms of education are expected to contribute to both individual and societal development as well as well-being: the underlying rationalization and justification for developing the knowledge-based economy (cf. Green, 2013).

Along with the new EU-level push towards a knowledge-based economy, the centralization processes and reforms of upper secondary education continued in Finland. 
The legislative framework regarding upper secondary education was revised in 1998 (Decrees 629/1998 \& 630/1998), and the central aim of the reform was to harmonize and unify the upper secondary education structure as a whole. Decision-making power was decentralized to the municipal scale and vocational degrees in the upper secondary level were to be restructured and unified into coherent three-year degrees. The new legislation stipulated that all upper secondary vocational programmes were to provide a general eligibility for higher education, and education providers were obliged to cooperate with other education providers in the region. As part of the aim of increasing the quality and popularity of vocational education, a new form of vocationally oriented higher education, the polytechnic, was established in the mid-1990s (Decree, 256/1995). These higher education institutions gradually adopted the English translation 'universities of applied sciences' (Interpellation, 1084/2005), reflecting harmonization aims within EU countries.

Irrespective of the external harmonization aims, internally the two paths of upper secondary education, GUS and VET, and their students were treated as different constituents of the emerging knowledge-based economy. GUS and VET were developed as two separate educational tracks. Whereas GUS was considered an extension of comprehensive education, providing a general education and preparation for higher education, the importance of VET was constructed more on the basis of societal and economic needs. Arguments related to workforce needs or the need to promote specific industries were introduced to justify student intake quotas for different fields of VET (Development plan, 2000).

The governmental documents point out how at the turn of the 21 st century, providing Finnish youth with an upper secondary education in line with anticipated future employment requirements and skills was considered essential: "From the 
perspective of lifelong learning and meeting the demands of working life, achieving upper secondary education is to be regarded as a minimum requirement" (Development plan, 2000: 30). Rapid changes in working life and technological advancements were regarded as reasons to further develop upper secondary education and to establish its status as a minimum level of education. At the same time, increasing concern arose over marginalized youth who failed to meet the new minimum requirement of achieving either a VET or GUS degree. Especially the transition from comprehensive to upper secondary education was regarded problematic from the perspective of securing a solid educational path and skilled citizen-subject formation. As a result, more resources were directed to addressing social exclusion and marginalization among youth.

\section{Competitive regions constitute a competitive state: Education as a regional issue} 2003-2011

After a decade of transitioning towards the post-Keynesian model and the gradual rejection of redistributive politics, regional issues became more visible in national educational policies (see also Kallunki et al., 2015). This is partly explained by the ascendence of the Centre Party-led governments. The Centre Party in Finland, in comparison to its European counterparts, has traditionally emphasized education along rural and regional development and this emphasis on regional issues was underlined in educational policy as well. Government programmes and educational development plans now began to address emerging regional disparities. An ageing population and simultaneous demographic polarization were identified as key challenges with implications for regional development and the organization of education (Development plan, 2004: 11). In the year 2007, educational attainment levels were lowest in rural and eastern and highest in urban and southern Finland: for instance, in Kainuu region, only $20 \%$ of the population aged 15 and older had acquired higher education whereas the 
respective percentage in the more urbanized Uusimaa region was 33.

The main educational reforms targeted higher education and aimed to establish a structural reform in GUS studies and the matriculation examination, which had been ongoing since 1995. Regarding VET, the main emphasis was on securing the structural changes in vocational education implemented in 2001 (Development plan, 2004: 39). In the government programmes, the rhetoric of the knowledge-based economy was employed to address educational needs at different geographical scales. The state perspective was drawn together with regional perspectives, since regions were regarded as important constituents of the knowledge-based society and were to be developed since "the success of the regions supports national economic growth and is reflected throughout the whole country" (Government programme, 2003: 27). VET especially was tightly linked to regional competitiveness and development of local labour markets: "Basic vocational education and training play an important role as a forger of skills that support regional competitiveness and regional development, and as a driver for the development of working life" (Development plan, 2004: 41). This reveals how education in Finland is tightly linked to state-led trajectories and regional development, as educational institutions are expected to provide a skilled workforce that contributes to economic growth and the competitiveness of the state and its regions (cf. Ahlqvist and Moisio, 2014).

Along with the regional competitiveness discourse, a central tenet of the government programmes was to increase equality among people and regions. This was to be done by focusing on regional specialties. The objective was to develop vocationally oriented education based on regional strengths and the needs of labour markets. New jobs in knowledge-intensive industries were understood to channel growth and draw highly educated citizens to certain growing cities and city-regions, 
while regions that were not considered forerunners in the growing knowledge-based economy were encouraged to find their own fields of specialization. This regional focus therefore entailed both delegating decision-making power to the local scale and simultaneously underlining the region's own responsibility and capacity to adapt.

The multiscalar dimensions of Finnish educational policy and rationalization are evident in the governmental educational plans, which are tightly intertwined with European-level educational policies. The educational policy documents indicate that upper secondary education should provide citizens with the necessary skills to survive in a globalizing world, that is, to be able to become global-minded and participate in the global economy. In GUS, language skills are emphasized, whereas in VET student mobility is seen as important (Development plan, 2007: 43). Educational discourse rooted in the knowledge-based economy underlines the capacities of adapting and being competitive in the ongoing internationalization and globalization processes.

\section{World's leading knowledge-based society in the age of austerity 2011-2019}

The global fiscal crisis of 2008 started to gradually influence the Finnish national economy when the actual need to balance the state economy became actualized through implementing austerity measures a couple of years later. The government programmes of 2011 and 2015 directly articulate that national educational policies have an important role in the balancing of the national economy. The respective development plan (2012) stated that educational policies are to be aimed at improving the structures and efficacy of the education system, in order to raise educational attainment levels and tackle early school leaving. This was considered important if the decreasing youth cohorts were to replace the retiring cohorts. The efficiency objective is manifested in the aim to reduce the amount of people studying several degrees in the upper secondary level, considered 
as "unnecessary overlapping upper secondary qualifications" (Development plan, 2012: 12).

Major reforms of upper secondary education that had long been planned were implemented. Knowledge and education was one of the six key projects of strategic action (Government program, 2015) during prime minister Sipilä’s government. The objectives of VET reform were to renew and integrate the funding system and steering systems and to improve the status of VET. Simultaneously, significant financial cuts were implemented in state educational budgets, and VET funding became based more on performance and efficiency. VET was to be reworked to "meet the skills and knowledge needs of the future" (Government proposal, 39/2017), to respond to the changing needs of the economy and adopt a competence-based and customer-oriented approach. Individual learning paths, flexible studies, and increasing cooperation with workplaces were emphasized. The aim of the GUS reform accepted in 2018 (Government proposal, 235/2018) was to increase the attractiveness of GUS and strengthen the quality of education and learning outcomes. Moreover, a student selection reform was implemented to streamline the transition to higher education (Government proposal, 41/2018). The established reforms manifest the ideas of improving efficiency and individualization of upper secondary education, which are imagined to benefit the knowledge-based economy and yield qualified and skilled citizen-subjects.

Policy documents from 2011 onwards demonstrate the stabilization of the knowledge-based discourse, which has become one of the central drivers of national educational policies. Political documents imply that Finland should continue to develop its knowledge-based economy and become the world's leading knowledge-based society (Government plan, 2015), wherein education would contribute to the 
development of the globalizing knowledge-based economy by producing qualified citizen-subjects. One of the key stated objectives of the Ministry of Education and Culture (MEC, 2017) is to raise the level of education and competence among the people and promote higher education. Higher education is explicitly linked to the narrative of the national success story by stating that research and innovation play a central role in promoting well-being and national competitiveness (MEC, 2017). The links between upper secondary education and the national agenda are more implicit and subtle: every young citizen is guided to upper secondary education and more attention is paid to youth who are considered marginalized, that is, those who have fallen out of the education and training system. By this means, upper secondary education is seen as an essential part of modern society and as crucial for an individual's successful transition to the labour market (Development plan, 2012: 31).

Examination of the governmental and educational documents reveals an underlying ambiguity. However highly appreciated education may be in educational policy documents, the actual implementation of educational politics has been less successful. Although educational attainment levels have increased, regional disparities still exist. Youth educational paths differ markedly between urban and rural regions. In 2018 , whereas in urban regions around $56 \%$ of ninth graders continued on to general education and $38 \%$ on to vocational education, in rural regions only $46 \%$ continued on to general and $48 \%$ on to vocational (Statistics Finland). Also, the regional differentiation in attainment levels is unlikely to diminish soon. Since 2011, Finnish governments have implemented major budget cuts in education that have raised concerns over the quality of education and regional disparities in educational accessibility throughout the country: the Regional State Administrative Agency (2016) reported that in 2015 the accessibility of upper secondary education had notably 
decreased, especially in the sparsely habited and rural northern and eastern parts of the country where structural changes in demographics and the economy hinder the organization of education. Whereas in southern Finland $90 \%$ of 16-year-old youths are situated proximate to at least one institution providing GUS and $88 \%$ have VET within 10 kilometres from their homes, in eastern Finland the respective percentages are 73 and 62 .

\section{Spatial justice and citizen-subject formation through scalar constructions}

The examination of the governmental and education documents between 1987 and 2019 shows how the state education reforms in Finland have been rationalized and justified by referring to particular spatial imaginaries and positionings of the knowledge-based economy with regards to the global, national and regional scales, and their interplay (cf. Delaney and Leitner, 1997; Jonas, 1994). The social and political construction of geographical scales is understood as a process in which conflicting rationalizations and interests arise and play out; thus discrepancy between the scales and places and their reasoning may occur (see Delaney and Leitner, 1997). The spatial imaginaries and scalar spatial justices are also visible in the specific citizen-subjects and spatialities Finnish educational policies construct.

The study of educational discourses illustrates how national-scale rationalizations were emphasized during the economic recession in the beginning of the 1990s. The question of national economic survival and competitiveness became evident again in the 21 st-century discourses, when global competition, national competitiveness, and education were drawn more tightly together along with the transition towards a post-industrial knowledge-based society. State-scale rationalizations are therefore entangled with international-scale and global-level developments and trends. Fostering internationalization and harmonizing education 
structures are seen as an inevitable measure in the struggle to keep up with the globalization and international competition that underpin the knowledge-based economy.

The rationalization of upper secondary education on the regional scale is twofold: educational possibilities are perceived as crucial not only in relation to citizens and their right to access education, but also in terms of the prospects of the regions. While the former pertains to the individual scale, the latter pertains to spatial justice on the regional scale. Our examination points out that the discourses of spatial and scalar dimensions regarding general and vocational upper secondary differentiate spatially. Rationalizations of GUS are more often linked to spatial justice in terms of an individual's equal opportunities and rights to participate in and have access to higher education. GUS is often seen as a path to higher education and linked to rising education levels, and thus to knowledge-intensive work and the increased human capital that is associated with individual well-being and success and considered crucial for a prospering knowledge-based economy. As the discourses concerning VET tend to focus more on the regional significance of VET and vocational institutions' capability to provide a skilled workforce to promote economic growth, VET is directly linked to the regional economy and directed at providing a skilled workforce to meet regional and national needs. In these discourses, space and spatial dimensions are addressed more in relation to regional significance than to equality of opportunities.

Examination of the upper secondary education reforms in Finland brings to light how changes in educational policies and educational reforms mirror the changing political climate and dominant economic ordering, contributing to the construction of educational subjectivities and the fostering of specific citizen-subjects (cf. Mitchell, 2019). Global economic turbulence has created a sense of continuous urgency around 
stabilizing Finland's competitive advantage in the global and the European knowledge economy. As a small state whose economy relies on export, Finland is seen to be especially vulnerable to the turbulence of the global markets, and "fostering specific capacities and qualities in the population" is conceived of as a possible solution to this dilemma (Moisio and Kangas, 2016: 273).

Examination of upper secondary education points out, however, that educational discourses do not address all youth in a similar manner, nor in a spatially just manner. The two upper secondary education paths differentiate with regards to the discourses of academic and vocational citizen-subjects and spatialities emerging in the subject formation. The academically oriented ideal citizen-subject of the knowledge-based economy, characterized by internationally minded human capital and skills, materializes primarily in urban areas and city-regions, and that is where the higher education institutions and labour markets have centralized. As practice-oriented citizen-subjects, vocational students are constructed more in terms of a regional yet mobile workforce and in terms of supporting regional competitiveness. Moreover, vocational education is perceived as an important component in preventing youth marginalization. The educational paths filter subjects not merely according to their repertoire of skills and expertise, but also according to their flexibility and mobility (cf. Martin and Prokkola, 2017). Adopting the doctrine of life-long learning from EU-level policies stretches the objective of being flexible and mobile to apply throughout the citizen-subjects lifespan. In the age of the knowledge-based economy, educational subjects are depicted as individual decision-makers who are adaptive and flexible, constructing an imaginary of flexible and adaptive citizen-subjects.

Throughout the period under observation, Finnish educational policies have adopted a more individualizing mode of spatial justice in educational policy discourses 
fostering personalized, flexible, and more efficient learning paths. The former ideal of universalism and equality has given way to a more neoliberal understanding of equity that emphasizes the libertarian ideal of individual choice and efficiency. In fact, individualization is utilized as a rationale for making study paths more effective. Enhancing efficiency has been one of the key points of emphasis of the Finnish educational reforms, one which has affected the entire education system, rationalized by the need to raise employment rates, tackle marginalization, and replace retiring cohorts in the labour markets. Therefore, all youth are guided to upper secondary education and the importance of vocational education and training is emphasized. Formal qualifications and degrees are regarded as prerequisites for fully participating in the knowledge-based society and economy. Albeit educational policies still regard education as significant in terms of individual well-being, the overall development reflects a shift towards a more economically driven rationale. This is manifested in reforms that aim to foster efficiency and enable flexible and individualized education paths, as well as faster employability and transition to labour markets, mirroring a wider transformation of governance and public administration (see Siljander, 2017).

If Finnish educational discourses have traditionally been presented as embracing welfare state policies, humanist ideals, and personal development, the present examination of recent educational reforms points out that educational discourses and rationalizations have been fundamentally reshaped in favour of a business-needs-driven agenda aimed at the creation of the "right sort" of entrepreneurial minds and human capital (see Moisio and Kangas, 2016; Welsh and Parsons, 2006). In addition, the findings of this paper highlight that these restructuring processes seem to be socially and spatially exclusive, differentiating places and educational subjects. Welsh and Parsons (2006) explain how in the wake of this discursive shift, justice in educational 
access and outcomes has become individualized. In this context, social and spatial justice is understood to materialize when citizens are given a possibility to choose from the sites and services on offer. When individuals are considered responsible for their own straitened circumstances, little attention is paid to spatial inequalities, cultural politics of recognition, or to social politics of redistribution.

\section{Conclusions}

This article analysed the spatial rationalizations of state education policy and reforms as well as the implications from the perspective of spatial justice in Finland. It provides a periodization of shifting spatial rationalizations of education concerning Finnish upper secondary education, and an analysis of what these changes have meant in terms of spatial justice and citizen-subject formation. We maintain that citizen-subject formation and youth educational paths are complex in nature and affected by various intersecting and entangled dimensions, including the agency of the citizen-subjects themselves (Mitchell, 2018) and their socio-economic background (Kosunen et al., 2020) for example. Moreover, we argue that in the context of national educational policies, the transition from comprehensive to upper secondary education represents a spatially consequential juncture in the educational path of an individual. Our examination illustrates how the different rationalizations of upper secondary education create spatial differentiations of certain places and differential inclusion of citizen-subjects - these spaces and policies regarding secondary education have far-reaching individual and societal consequences.

Studying the rationalizations of education policy and educational reforms sheds light on the prevailing societal values and spatial inequalities in education. In the case of Finnish educational policies, the importance of upper secondary education has increased, and it has to a greater extent fallen under the purview of economic 
rationalization. The analysis underlines that the overall emphasis of spatial rationalization has shifted towards an economic calculus emphasizing labour market needs and a competitiveness-oriented mode of reasoning. Adoption of the knowledgebased economy narrative builds on a discovery that education should contribute to both individual well-being and societal development primarily through economic development (Hill and Rock, 1990). Such trajectories of neoliberalization, individualization, and privatization can be found in many countries and educational systems around the globe (cf. Mayo, 2015; Mitchell, 2018), but in the case of the predominantly public Finnish education system, which is often praised for its social and spatial equality, these discursive shifts challenge a cornerstone of the welfare state and its educational policies.

Our examination also highlights the ambivalence between scalar rationalizations and material and societal development. Although education may be highly appreciated in national-scale educational politics and discourses, the implementation of educational politics may create contradictions between the scales. In the Finnish context, pursuing education has gained more importance and the importance of education is rationalized in multiple spatial scales, from the individual level to regional and state building, and with respect to global competition. Spatial justice in terms of distributive justice has, however, decreased and politics of redistribution seems hard to establish under current neoliberal agendas.

Moreover, we suggest that educational policies that are seen to contribute to fostering the knowledge-based economy are exclusive and differentiate places and citizen-subjects in terms of how they are able to participate in the knowledge-intensive economy. From the perspective of recognitive spatial justice, certain paths and citizensubjects are seen as more desirable while those beyond the dominant discourse of the 
knowledge-based economy remain unrecognized (cf. Fraser, 1997; Gewirtz, 1998). The knowledge-based economy seems to foster and value specific symbolic and cultural aspects and spatially centralized structures and citizen-subjects: the primary sites of knowledge production, labour markets for highly educated citizen-subjects, and higher education institutions located in urban areas and city-regions. Places and regions that are not specializing and competitive in the areas of knowledge-based economy are left behind and considered not worth investing in (Rodríguez-Pose 2018); however, these places in particular would benefit from fostering educational opportunities, among others. We argue that by constructing narrow and exclusive imaginaries of economically driven rationalizations, the current hegemonic Finnish education policy discourse fails to recognize and value the diversity and difference of citizen-subjects and alternative economic rationalities.

\section{Acknowledgements}

We would like to thank Johanna Sitomaniemi-San and anonymous referees for their valuable comments.

\section{Declaration of conflicting interests}

The author(s) declared no potential conflicts of interest with respect to the research, authorship, and/ or publication of this article.

Funding The authors disclosed receipt of the following financial support for the research, authorship, and/or publication of this article: The Finnish Cultural Foundation's North Karelia Regional Fund and Kyosti Haataja Foundation. 


\section{ORCID iD}

Marika Kettunen https://orcid.org/0000-0001-6067-569X

\section{Notes}

1. In the Finnish school system 9th grade is the final year of compulsory school, during which students must apply to upper secondary education. The system is competitive: whereas the selection of students to GUS is mostly based on success in previous studies, the selection to VET can be based on entrance and aptitude tests and work experience as well as on success in previous studies. It is possible to combine GUS and VET into a dual-degree or acquire vocational qualifications through apprenticeship training. While GUS and VET are the two main paths, it is also possible to apply to additional comprehensive education or preparatory education if the student has not gained a study place in upper secondary education. Only GUS and VET provide eligibility for higher education.

2. Sivistys is not easily accurately translated. It might be translated as 'civilized', referring to the German Bildung tradition (see Siljander, 2017 on Finnish Bildung tradition). In this paper, we translate it as 'education'. For a brief etymology of sivistys, see Sitomaniemi-San (2015: 131-132).

\section{References}

Ahlqvist T and Moisio S (2014) Neoliberalisation in a Nordic state: From cartel polity towards a corporate polity in Finland. New Political Economy 19(1): 21-55.

Ahonen S (2001) The end of the common school? Change in the ethics and politics of education in Finland towards the end of the 1900s. In: Ahonen S and Rantala J (eds) Nordic Lights: Education for Nation and Civic Society in the Nordic Countries 1850-2000. Studia Fennica Historica. Helsinki: Suomalaisen Kirjallisuuden Seura, pp. 175-203.

Alestalo M (1993) The rise of neo-liberalism. Science \& Technology Studies 6(2): 3547. 
Armila P, Käyhko M and Pöysä V (2018) On the educational edges of a learning society: The Finnish hinterland as a framework of educational choices for young people. Journal of Youth Studies 21(9): 1198-1215.

Ball SJ (1997) Policy sociology and critical social research. British Educational Research Journal 23(3): 257-274.

Beach D (2017) Whose justice is this! capitalism, class and education justice and inclusion in the nordic countries: Race, space and class history. Educational Review 69(5): 620-637.

Bernelius V and Vaattovaara M (2016) Choice and segregation in the "most egalitarian" schools: Cumulative decline in urban schools and neighbourhoods of Helsinki. Urban Studies 53(15): 3155-3171.

Butler T and Hamnett C (2007) Geography of education: Introduction. Urban Studies 44(7): 1161-1174.

Delaney D and Leitner H (1997) The political construction of scale. Political Geography 16(2): 93-97. Development plan (n.d), Ministry of Education/Ministry of Education and Culture. Development plans for education and research 19872012.

Dikeç M (2001) Justice and the spatial imagination. Environment and Planning A: Economy and Space 33(10): 1785-1805.

Dillabough JA, et al. (2016) Gender, social justice and citizenship in education. In: Peterson A (ed.) The Palgrave International Handbook of Education for Citizenship and Social Justice. London, UK: Palgrave Macmillan, pp.49-71.

Dovemark M, Kosunen S, Kauko J, et al. (2018) Deregulation, privatisation and marketisation of Nordic comprehensive education: Social changes reflected in schooling. Education Inquiry 9(1): 122-141.

European Parliament (2000) Lisbon European Council 23 and 24 March 2000

Presidency Conclusions. Available at: www.europarl.europa.eu/summits/lis1_en.htm (accessed 14 November 2019).

Fairclough N (2010) Critical discourse analysis: The critical study of language (second edition). Harlow: Pearson.

Farrugia D (2016) The mobility imperative for rural youth: The structural, symbolic and non-representational dimensions rural youth mobilities. Journal of Youth Studies 19(6): 836-851. 
Finnish Parliament (n.d), Government proposals, Decrees, Acts, Interpellations 19942018. Eduskunta/Parliament, Valtiopäivä-asioiden ja -asiakirjojen haku/Finnish Parliament electronic document search.

Francis B, Mills M and Lupton R (2017) Towards social justice in education:

Contradictions and dilemmas. Journal of Education Policy 32(4): 414-431.

Fraser N (1997) Justice Interruptus: Critical Reflections on the 'Postsocialist' Condition. Abingdon, UK: Routledge.

Gewirtz S (1998) Conceptualizing social justice in education: Mapping the territory. Journal of Education Policy 13(4): 469-484.

Gewirtz S (2006) Towards a contextualized analysis of social justice in education. Educational Philosophy and Theory 38(1): 69-81.

Government program (n.d) Valtioneuvosto/Finnish Government. Government programmes 1987-2019. Available at: http://valtioneuvosto.fi/tietoa/historiaa/.

Green A (2013) Education and state formation. In: Green A (ed) Education and State Formation. Europe, East Asia and the USA. London: Palgrave Macmillan UK, pp. 82-114.

Harvey D (2005) A Brief History of Neoliberalism. Oxford: Oxford University Press. Hiilamo H (2014) Solidarity in a Nordic welfare state: The case of Finland. In: Pessi $\mathrm{AB}$ and Laitinen A (eds) Solidarity: Theory and Practice. Lanham: Lexington Books, pp.299-316.

Hill E W and Rock H M (1990) Education as an economic development resource. Environment and Planning C: Government and Policy 8(1): 53-68.

Holmberg L, Kalalahti M, Varjo J, Kivirauma J, Mäkelä M-L, Saarinen M, Zacheus T and Janhukainen M (2018) Educational trajectories of immigrant-origin youths in Finland: a mixed methods analysis. Journal of Education and Work 31(7-8): 563-578, DOI: 10.1080/ 13639080.2018.1549728

Järvinen T and Vanttaja M (2001) Young people, education and work: Trends and changes in Finland in the 1990s. Journal of Youth Studies 4(2): 195-207.

Johannesson I A, Lindblad S and Simola H (2002) An inevitable progress? Educational restructuring in Finland, Iceland and Sweden at the turn of the millennium. Scandinavian Journal of Educational Research 46(3): 325-339.

Jonas A E (1994) The scale politics of spatiality. Environment and Planning D: Society and Space 12(3): 257-264. 
Jones R, et al. (2019). Re-conceptualising territorial cohesion through the prism of spatial justice. In: Lang T and Gormar F (eds): Regional and Local Development in Times of Polarisation: Re-Thinking Spatial Policies in Europe. Singapore: Palgrave Macmillan, pp.97-120.

Kallio KP and Mitchell K (2016) Introduction to the special issue on transnational lived citizenship. Global Networks 16(3): 259-267.

Kallunki J, Koriseva S and Saarela H (2015) Suomalaista yliopistopolitiikkaa ohjaavat perustelut tuloksellisuuden aikakaudella. Kasvatus ja Aika 9(3): 117-133.

Kivinen O, Hovi R and Rinne R (1989) Komitealaitos, Koulutusmietinnot ja Koulutuspolitiikan Oikeutus. Ammatillisen ja Akateemisen Koulutuksen Oikeutusperustelujen Muutokset Suomalaisissa Koulutusmietinnoissä 1860Luvulta 1980-Luvun Lopulle. Turku: Annales Universitatis Turkuensis. Series C 73.

Kosunen S, Bernelius V, Seppänen P, et al. (2020) School choice to lower secondary schools and mechanisms of segregation. Urban Education 55(10): 1461-1488. Lampinen O (1998) Suomen Koulutusjarjestelmän Kehitys. Tampere: TammerPaino Oy.

Laukia J (2013) Tavoitteena sivistynyt kansalainen ja tyontekijä. Ammattikoulu Suomessa 1899-1987. PhD Thesis, University of Helsinki, Helsinki. MacIntyre A (1988) Whose Justice? Which Rationality? London: Duckworth. Martin L and Prokkola EK (2017) Making labour mobile: Borders, precarity, and the competitive state in Finnish migration politics. Political Geography 60: 143153.

Mayo P (2015) Hegemony and Education under Neoliberalism. New York: Routledge. Miller P and Rose N (2008) Governing the Present: Administering Economic, Social and Personal Life. Cambridge: Polity Press.

Ministry of Education and Culture (MEC) (2017) Background Material for the Vision for Higher Education and Research for 2030. Helsinki: Ministry of Education and Culture.

Ministry of Education and Culture (MEC) (2019) Finnish Education System. Available at: https:// minedu.fi/en/education-system (accessed 7 November 2019).

Mitchell K (2018) Making Workers: Radical Geographies of Education. London: Pluto Press. 
Mitchell K (2019) Changing the subject: Education and the constitution of youth in the neoliberal era. In: Skelton T and Aitken SC (eds) Establishing Geographies of Children and Young People. Singapore: Springer Nature Singapore Pte Ltd., pp. $317-335$.

Moisio S and Kangas A (2016) Reterritorializing the global knowledge economy: An analysis of geopolitical assemblages of higher education. Global Networks 16(3): 268-287.

Paasi A (2005) Globalisation, academic capitalism, and the uneven geographies of international journal publishing spaces. Environment and Planning A: Economy and Space 37(5): 769-789.

Patomäki H (2007) Uusliberalismi Suomessa. Helsinki: WSOY.

Peer V and Penker M (2016) Higher education institutions and regional development. International Regional Science Review 39(2): 228-253.

Power S (2012) From redistribution to recognition to representation: Social injustice and the changing politics of education. Globalisation, Societies and Education 10(4): 473-492.

Rawls J (1971) A Theory of Justice. Cambridge: The Belknap Press of Harvard University Press.

Regional State Administrative Agency (2016) Aluehallintovirasto. Toisen asteen koulutuksen saavutettavuus hieman heikentynyt. Available at: www.avi.fi/web/avi/-/toisen-asteen-koulutuksen-saavu tettavuus-hiemanheikentynyt (accessed 23 January 2020).

Rodríguez-Pose A (2018) The revenge of the places that don't matter (and what to do about it). Cambridge Journal of Regions, Economy and Society 11(1): 189-209.

Saari J, Inkinen A and Mikkonen J (2016) Koulutuksen alueellinen tasa-arvo ja segregaatio. Otus 54/2016

Siljander P (2017) School in transition. The case of Finland. In: Siljander P, Kontio K and Pikkarainen E (eds) Schools in Transition. Rotterdam, Netherlands: Sense Publishers, pp.191-212.

Simola H, Rinne R and Kivirauma J (2002) Abdication of the education state or just shifting responsibilities? The appearance of a new system of reason in constructing educational governance and social exclusion/inclusion in Finland. Scandinavian Journal of Educational Research 46(3): 247-264. 
Sitomaniemi-San J (2015) Fabricating the teacher as researcher: A genealogy of academic teacher education in Finland. PhD Thesis, University of Oulu, Oulu.

Smith E (2012) Key Issues in Education and Social Justice. SAGE Publications Ltd.

Soja E W (2010) Seeking Spatial Justice. Minneapolis: University of Minnesota Press.

Staeheli L (2011) Political geography: Where’s citizenship? Progress in Human Geography 35(3): 393-400.

Taylor S (2004) Researching educational policy and change in 'new times': Using critical discourse analysis. Journal of Education Policy 19: 433-451.

Tervasmäki T, Okkolin MA and Kauppinen I (2020) Changing the heart and soul? Inequalities in Finland's current pursuit of a narrow education policy. Policy Futures in Education 18(5): 648-661.

Thiem C (2009) Thinking through education: The geographies of contemporary educational restructuring. Progress in Human Geography 33(2): 154-173.

Varjo J and Kauko J (2008) Age of indicators: Changes in the Finnish education policy agenda. European Educational Research Journal 7(2): 219-231.

Waitoller FR and Annamma SA (2017) Taking a spatial turn in inclusive education. In: Hughes MT and Talbott E (eds) The Wiley Handbook of Diversity in Special Education. Chichester, UK; Hoboken, NJ: John Wiley and Sons, pp. 23-44.

Warrington M (2008) Decisions and transitions: Meeting the needs of the "knowledge economy. Environment and Planning C: Government and Policy 26(5): 924937.

Welsh PJ and Parsons C (2006) Social justice, service delivery and welfare reform. The politics of deprivation, disaffection and education in the district of Thanet. Education, Citizenship and Social Justice 1(1): 39-57.

Young IM (1990) Justice and the Politics of Difference. Princeton: Princeton University Press. 